\title{
A Nested Logit Model of Recreational Fishing Demand in Alaska
}

\author{
RICHARD T. CARSON \\ University of California, San Diego \\ W. MICHAEL HANEMANN \\ University of California, Berkeley \\ THOMAS C. WEGGE \\ TCW Economics
}

\begin{abstract}
Key words Travel cost analysis, bioeconomic modeling.
JEL Classification Codes Q26, Q22, C35.
\end{abstract}

\section{Foreword}

This paper (and the large study behind it) was in some ways a labor of love. We set out to build a discrete choice model to predict recreational fishing behavior that would extend the literature along several dimensions. Our interest in doing so stemmed from earlier work that we were individually or collectively involved in. Hanemann's dissertation $(1978)^{1}$ suggested the power of the discrete choice random utility model (RUM) to look at a large set of recreational alternatives, in this case beaches in the Boston area, and identify the role that attributes like water quality played in consumer choice behavior. ${ }^{2}$ Carson worked as a research assistant on a large recreational demand project for Jeff Vaughan and Cliff Russell at Resources for the Future (Vaughan and Russell 1982a,b). This project attempted to expand the travel cost framework to dealing with water quality issues and different types of fishing on a large spatial scale using the 1975 Survey of Hunting, Fishing, and Wildlife-Associated Recreation and a much smaller survey undertaken by the research team aimed at gathering specific information for placing a monetary value on different types of fishing days. The project used a discrete choice framework and had bumped up against both computational limits and limits of what could be estimated using

Richard T. Carson is a professor in the Department of Economics, University of California, San Diego, La Jolla, CA 92093 (email: rcarson@ucsd.edu). W. Michael Hanemann is a Chancellor's Professor, Department of Agricultural and Resource Economics, University of California, Berkeley, Berkeley, CA 94720 (email: Hanemann@) are.berkeley.edu). Thomas C. Wegge is a Principal Economist, TCW Economics, $27569^{\text {th }}$ Avenue, Sacramento, CA 95818 (email: ).

This paper was originally presented at the 1989 Western Economic Association Conference, Lake Tahoe, Nevada. Funding for the work reported on in this paper was provided by the Alaska Department of Fish and Game. The opinions expressed are those of the authors. We thank George Parsons for his key role in bringing this paper out of the gray literature and to Ted McConnell and V. Kerry Smith for helpful comments on the foreword to this paper.

${ }^{1}$ A very early version of this work was published as Binkley and Hanemann (1978).

${ }^{2}$ At about the same time, Edward Morey was pursuing a different but related approach in his dissertation on the valuation of ski sites. We became aware of Morey's work after it was published (Morey 1981). A starting point for Hanemann's dissertation research was the early study by Burt and Brewer (1971). This paper did not consider quality attributes or corner solutions that Hanemann sought to incorporate into a system of consumer demand equations. When he commenced this research in May 1974, Hanemann contacted Burt and Brewer to see if he could obtain their data but learned that it had recently been discarded. 
data from government surveys being implemented at the time. Hanemann had a fruitful collaboration with Nancy Bockstael and Ivar Strand on the EPA-funded study of the Chesapeake Bay, where he was involved mainly in the theoretical formulation of demand models rather than data collection or estimation. ${ }^{3}$ He also collaborated with Ivar Strand and Thomas Wegge of Jones \& Stokes, a Sacramento-based environmental consulting company, in all phases of a study of marine recreational fishing in Southern California for the National Marine Fisheries Service (Wegge, Hanemann, and Strand 1986). ${ }^{4}$ These studies whetted our appetite for the opportunity to engage in a large-scale data collection effort for modeling discrete/continuous choice behavior.

By the mid-1980s, the original zonal travel cost model as suggested by Hotelling and implemented by Clawson and Knetsch (1966), while still a workhorse of applied work for government agencies, had largely run out of steam from an academic perspective. The properties of the model had been well explored (e.g., Gum and Martin 1975; Dwyer, Kelly, and Bowes 1977), and its problems loomed large once one moved away from very simple situations and the limited origin-destination data that was typically available in secondary datasets (e.g., Smith and Kopp 1980). Interest in moving to a discrete choice RUM framework was driven by the desire to value marginal changes in the characteristics of sites and in valuing the opening and closing of sites. ${ }^{5}$

What we wanted to do required much more extensive data than had been collected in the past. This put such a study out of the reach of the pure academic realm and even beyond what most state or federal agencies were used to funding. By happenstance, we did find an agency with a serious problem, a willingness to find the resources needed to resolve it, and, perhaps most importantly, one that was willing to consider the use of economic values in making its decisions. The Alaska Department of Fish and Game (ADFG) was wrestling with politically controversial issues related to managing the stocks of the major salmon species, determining funding priorities for different hatchery programs, and allocating the catch among commercial and recreational fishermen. ADFG felt it needed a valuation model for sport fishing with considerable spatial, temporal, and species resolution. Because of the distinctively compressed timing of salmon runs at particular spawning sites, ADFG needed to be able to evaluate decisions involving actions on the scale of a particular week, a particular species of salmon, and a narrowly defined location. ADFG also recognized the importance of site substitution; it needed to know how much closing one site to sport fishing would increase fishing pressure at other sites. ADFG put out a request for proposals to develop such a valuation model, and we ended up winning the contract. Jones \& Stokes would be in charge of the large data collection effort and would also conduct a companion analysis of sport fishing expenditures and the resultant impact on the Alaskan economy. ${ }^{6}$

From our perspective, Alaska was ideal. Geographically, the area of analysis was self contained. Alaskans fish at a greater rate and more often than any other state. Much of the population lives in a few locations. A fairly sparse road system coupled with an emphasis on catching different species of salmon near the mouths of rivers helped to define fishing sites. Mike Mills, our project officer at AFDG, had an encyclopedic knowledge of fisheries and fishing in Alaska.

\footnotetext{
${ }^{3}$ See Hanemann (1984a,b); Bockstael, Hanemann, and Strand (1986); Bockstael, Hanemann, and Kling (1986); and Bockstael, Strand, and Hanemann (1987).

${ }^{4}$ Another study done at roughly the same time on the Pacific Coast using a discrete choice approach which influenced our work was Rowe et al. (1985).

${ }^{5}$ Another framework for valuing marginal changes in attributes, the hedonic travel cost model, was advanced by Brown and Mendelsohn (1984) and Mendelsohn (1985). At the time our study was undertaken, it was unclear which paradigm would prove more useful, but ultimately the hedonic travel cost model appeared to be less reliable in its implementation (e.g., Smith and Kaoru 1987).

${ }^{6}$ Our surveys on fishing trips collected extensive information on expenditures by categories. Mike Costanzo, one of the report's coauthors, worked on using this data to help build an input-output model that was used to predict the impacts of recreational fishing on the Alaskan economy (Jones \& Stokes 1987).
} 
The first major decision that we made was to put most of the money from the contract into data collection in order to be sure to get the right data, knowing that this meant that we would largely be working for free on the data analysis. The study was one of the first travel cost studies to use focus groups to understand how recreational fishing decisions are made. ${ }^{7}$ This gave us substantial insight into what variables to collect and how they might be used in modeling anglers' choice behavior. ${ }^{8}$

Some of the things we learned are as follows. First, it became clear that the size of vehicle matters greatly; some anglers have small cars while others have large trucks or even RVs. This led us to collect information on the type of vehicle owned by respondents so that we could employ individualized travel costs. ${ }^{9}$ Second, we found out that for people who have a cabin, loosely defined as anything from a nicely appointed cottage to a lean-to shack, this had a major impact on where (and how frequently) they chose to go fishing. The possession of a cabin entails a lower cost, better knowledge, and a type of habit formation somewhat different from what was then generally considered in the literature. Without this variable, the modeling would not have gone nearly as well. ${ }^{10}$ Third, we had to develop a definition of leisure time availability that fit the reality that an an single point in time any Alaskan seemed to be able to take off for a couple of days of nonstop fishing, although most were not able to do this week in and week out. Fourth, there is a relatively high degree of angler awareness of current fishing opportunities in Alaska because ADFG puts out a weekly announcement describing fishing conditions and stating where the salmon are expected to be running. We got a sense that anglers' perceptions are based partly on this information and partly on their knowledge of what happened last season. The combination of harvest estimates from the previous year plus the ADFG announcements allowed us to create variables which avoided the endogeneity of the respondent's current catch as a proxy for fishing quality. Fourth, we also saw that there was likely to be a strong temporal pattern to recreational fishing, especially in the shoulder portion of the fishing season (May and September), influenced by when particular species of salmon are running and how cold it is outdoors. It seemed like everyone who fished in Alaska went somewhere to fish over the Fourth of July. This temporal dimension ultimately led us to build a model whereby respondents made recreational fishing choices week by week over a 22-week fishing season. The propensity to fish was allowed to vary weekly, and site choice varied weekly with changes in crowding and an index of fishing quality that took considerable effort to develop.

In the focus groups we were also struck by the tremendous heterogeneity in fishing behavior and preferences. Some people target a specific fish species and then look for the best site, while others pick a site and fish for whatever is there. Some people choose sites to avoid crowds, while others actively seek out places with many other people. This observation influenced how we structured the model that was eventually estimated.

We attempted to avoid sample selection problems by first locating people who might fish during the coming season using a first-stage screening survey of the general Alaskan population. We attempted to avoid recollection problems by sending respondents a diary in which to record their trips and collected that information in two waves during the fishing season. The first wave covered fishing in May, June, and July, and the second covered August and September. We made an effort to minimize non-response by sending out a composite survey for the whole fishing season to those who did not respond to the first wave. We attempted to avoid problems with identifying geographic locations by

\footnotetext{
${ }^{7}$ Carson was very familiar with focus groups through his collaboration with Robert Mitchell at Resources for the Future, prior to coming to Berkeley for his Ph.D.

${ }^{8}$ The focus groups even helped to provide what turned out to be an ideal incentive to help get a high response rate - entry into a drawing for a free trip to Hawaii during the winter.

${ }^{9}$ This practice is still infrequent in modeling travel cost models and only recently has this issue been explored in some depth (Hagerty and Moeltner 2005).

${ }^{10}$ Boat ownership was also identified as a key factor that likely influenced site choice.
} 
providing maps and lists of sites in the survey instrument. Examples of how to record trip information were provided to help reduce respondent recording errors.

Given the data, the major challenge in formulating and estimating a model of choice behavior was the sheer complexity of the potential angler choices. In each of the 22 weeks, an angler could potentially choose among 29 sites, and, at each site, among up to 13 species. An angler also could choose how many times to fish that week. In all, there were almost 30 million potential choice alternatives. It was clear to us that this structure called for a nested logit model, and we ended up developing a model with four levels of nesting. At that time, no one had ever estimated a model with so many levels of nests.

Programming the estimation of this complex model and securing the computational resources to conduct the estimation were monumental challenges. At the time, statistical packages with conditional logit models, such as LIMDEP, were just becoming available. However, they were too limited for our needs. Our estimation problem was irregular in the sense that the choice set varied week by week (e.g., if there were no king salmon at a site in a particular week that site could not be chosen for king salmon fishing). Beyond this, our choice problem was just too big given the usual way of trying to estimate the model in the computer's RAM memory. We were very fortunate that Dan Steinberg, a colleague of Carson's, had a software company, Salford Systems, which was developing a LOGIT package at the time. Steinberg was willing to make many of the modifications we needed because he saw what we were doing as the wave of the future. A number of these enhancements were incorporated into the next version of LOGIT and eventually into other packages for estimating conditional logit models. Steinberg had a long-standing working relationship with Scott Cardell, who is credited with first proposing the nested logit model, and the two of them were an invaluable resource in dealing with the statistical properties of the model we were estimating. ${ }^{11}$

We used just over 2,000 hours on Digital Equipment Corporation (DEC) VAX minicomputers and six hours on what at the time was one of the world's fastest supercomputers, a CRAY XMP/48, at the San Diego Super Computer Center. ${ }^{12}$ The VAX minicomputers we commandeered comprised the bulk of UCSD's instructional computers. They were being used lightly and sporadically for classes during the summer and, to use them, we had to structure the programs so that they would essentially go into background and out of memory if the machines were being used by students. The VAX computers had eight megabytes of memory, which was enormous relative to PCs of the day. For much of our project, this eight megabytes of memory (minus the space taken by the operating system) was the critical limitation on what could be estimated. Now the PC sitting on your desk is likely to have two plus gigabytes of memory and 5,000+ times the raw processing speed. Even the $\$ 20$ million Cray XMP/48, which was several hundred times faster and had double the memory of the VAX, pales in comparison with the common desktop PC of today. With software packages that are now readily available, today's research would face no computational challenge in getting our entire model to run in hours rather than the months it required.

This paper languished with regard to publication because other events intervened, and we were never quite satisfied that all of the loose ends had been tied up. ADFG was pleased with the study, and as soon as we submitted our final report, they commissioned

\footnotetext{
${ }^{11}$ Some of our modeling issues also play a role in Cardell's (1997) reformulation of the nested logit model in a way that made it amenable to underpinning a number of applied I/O applications (Berry 1994). One output of our collaboration with Steinberg was the Carson, Hanemann, and Steinberg (1990) paper that used stated preference data from the Jones \& Stokes (1987) report to estimate what turns out to be the first choice experiment in the recreational demand literature to use the modern form of a multinomial choice question with an experimental design encompassing multiple attributes and a no purchase alternative modeled with a nested logit formulation.

${ }^{12}$ Our project was one of the first social science applications to run at any of the national super computer centers which were set up by the National Science Foundation in the mid-1980s.
} 
a similar study covering the southeastern part of the state. ${ }^{13}$ This broke little new ground methodologically and consumed time that would otherwise have been spent refining the Southcentral study for publication as a journal article, but we felt obliged to accommodate ADFG. While the Southeast study was under way, the Exxon Valdez oil spill occurred, and we were approached by the federal government and by the Alaska Attorney General to work on this (Carson et al. 1992).

With regard to this study, there was more that we wanted to do, including: $i$ ) moving from a sequential limited information maximum likelihood approach to a full information likelihood approach; $i$ i) testing the sensitivity of the results to alternative nesting structures; iii) allowing for more interactions between respondent characteristics and site attributes along the lines of what we did with crowding as a way for allowing for more heterogeneity in respondent preferences; and iv) allowing explicitly for temporal variation in some of the parameters. One modification that did get done later was the estimation of a truncated count data model to predict the number of trips taken for those who took a trip in a particular week where the inclusive value from the lower branches of the tree served as predictor (Grogger and Carson 1991). This effectively would have modeled the top branch of the tree in terms of a "fish/no fish this week" decision and then, if fish, how many times in the week, so that the resulting tree had five - not four-levels. We also wanted to explore issues related to non-linearity of welfare measures in terms of the estimated parameters and the implications of how the specification of the error component influenced estimates of those welfare measures. ${ }^{14}$ The complexity of the model in conjunction with the computational limits we faced largely forced us into considering a representative agent formulation. Indeed, we had to develop a PC program based on the model parameters that would run on a PC of the day so that the ADFG could use it to predict the response of anglers to regulatory actions, such as closing down sites for king salmon fishing in a particular week. This program was used for many years and must have been one of the early interactive bioeconomic modeling tools used by a government agency. ${ }^{15}$

After the Exxon Valdez study, two of us, Carson and Hanemann, became heavily involved in the contentious debate over the use of contingent valuation surveys, while Wegge had moved on to open his own firm as a private consultant. Over time, the study took on a life of its own in the grey literature. Since it was not widely distributed or posted on the web, the study's main influence up to now was limited to researchers who had access to a hard copy of this paper or the larger report. ${ }^{16}$

Richard T. Carson

W. Michael Hanemann

Thomas C. Wegge

\section{Introduction}

An important objective of fishery management is to provide sport anglers with a highquality recreation experience. Many factors contribute to the overall quality of sport fishing. Certain factors, such as weather and other environmental conditions, are beyond the effective control of fishery managers. Other factors, however, such as onsite facilities,

\footnotetext{
${ }^{13}$ Jones \& Stokes Associates (1991).

${ }^{14}$ These issues were laid out in Hanemann (1984b) in the context of a binary discrete choice contingent valuation question but were just as relevant to this study.

${ }^{15}$ The nested logit structure of the model made it particularly easy to explain to fisheries managers how changes at one location reverberated throughout the system they were managing.

${ }^{16}$ See for instance, Freeman (1995); Kaoru, Smith, and Liu (1995); Morey, Shaw, and Rowe (1991); Provencher and Bishop (1997); and Train (1998). The report has been scanned and is now available as a pdf file along with the survey questionnaires and datasets used (http://www.econ.ucsd.edu/ rcarson).
} 
degree of congestion, and fish stocks available for harvest are controllable and can significantly influence the fishing experience.

The economic value of sport fishing often is measured in terms of anglers' total willingness to pay for the sport fishing opportunities. Quality plays an important role in this value assessment. As the quality of the experience increases, so do the measurable benefits, thereby providing the economic justification for implementing specific management actions.

The role of quality in fishery management is especially important in Alaska, where sport fishing is associated with visions of catching trophy-sized fish in a wilderness area. Sport fishing is a dominant activity for outdoor-oriented Alaskans and a major contributor to the state and many local economies. At any given time during the long summer months, sport anglers in the Southcentral region can fish for trout at more than 20 different locations, for three or four different species of salmon, or for a variety of saltwater species, including 300 to 400 pound halibut. These sport fishing opportunities can be found within a several-hour drive of the Anchorage area.

The highly variable conditions associated with this diversity, however, present a formidable challenge to researchers interested in modeling angler behavior. The substantial changes that occur in fishing opportunities as areas open and close and as species change require an analytical framework with a temporal resolution more disaggregated than at the seasonal level. Characteristics common to sport fisheries elsewhere, such as congestion and access problems, also contribute to the analytical complexity.

\section{Study Objectives and Scope}

In this article, we report selected results from a recently completed study (Jones \& Stokes 1987) on the economic values associated with sport fishing in Southcentral Alaska (figure 1). The study involved the development of sport fishing demand models to analyze the behavior of resident and nonresident anglers in a regional context. The major analytical objectives of the study were to estimate:

- Expenditures of sport anglers by water body fished and by species sought and the economic impact of total angler spending on sport fishing in Southcentral Alaska at four levels: Kenai Peninsula, Anchorage area, remainder of Alaska, and outside of Alaska; and

- $\quad$ Nonmarket values (or consumer surplus) of sport fishing by water body fished and species sought. These values are the benefits to anglers over and above the expenditures they make to participate in sport fishing.

Although the study examined the demand of both resident and nonresident anglers for winter as well as summer sport fishing opportunities, this article focuses only on resident angler demand for summer sport fishing. This activity, which comprised more than $80 \%$ of total sport fishing trips in Southcentral Alaska in 1986, is considered more responsive in the short run to changes in site quality condition than all other activities, such as nonresident sport fishing or resident angler winter fishing. Because of this important relationship, the analysis requires explicit consideration of how changes in site quality affect angler demand. Results from application of the model for deriving net willingness to pay estimates and for analyzing the effects on demand from closure of a site during the sport fishing season also are presented. 


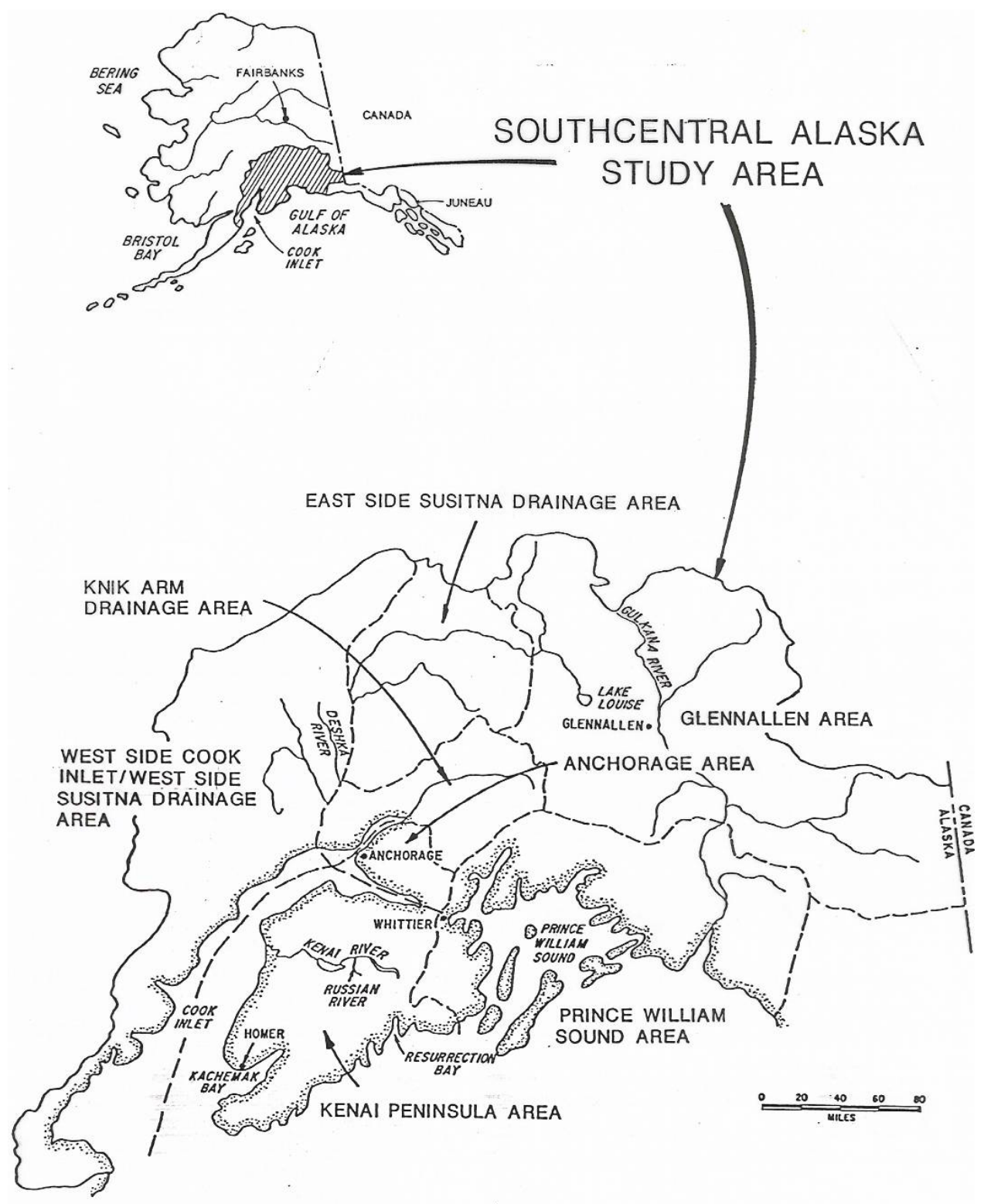

Figure 1. Southcentral Alaska Study Area

\section{Modeling Approach}

Significant advancements have been made in recent years in the development of recreation demand models capable of analyzing how quality associated with recreation sites affect angler behavior. Mendelsohn (1985) categorizes these models into three basic types. The first type is partitioning, in which heterogeneous goods (in this case, sport fishing sites) are segmented into fine enough categories so that all sites within a category can 
be treated as a similar good. A second type is the hedonic methodology, in which sport fishing sites are treated as bundles of homogeneous characteristics.

A third type selected for this study is what Mendelsohn calls the indexing approach. Similar to partitioning models, the indexing approach explicitly deals with how to choose one site (or species) among many. Similar to the hedonic approach, however, these models treat the choice as an explicit function of site characteristics. Anglers are assumed to generate cardinal rankings of the available sites based on objective characteristics of the sites. For the reference study, a discrete choice type of index model was selected in which angler choices on participation, target species, and sites at which to fish were evaluated as a series of discrete choices.

Resident angler demand was analyzed using weekly data on the sport fishing activities of 1,063 respondents over the 22-weeks from May 1, 1986 to September 30, 1986. The data were collected in a multi-phased mail survey. In May 1986, Alaskan households were randomly selected from occupant and voter registration lists for a survey to identify households who planned to fish in $1986 .{ }^{17}$ In early August, a questionnaire requesting information on all trips taken during May, June, and July was then mailed to fishing households identified from the first survey. ${ }^{18} \mathrm{~A}$ follow-up questionnaire was mailed in October requesting trip information for August and September. ${ }^{19}$ All trips reported throughout the 22-week season were assigned to one of the weeks.

The use of weekly data on sport fishing trips represents a major innovation in the analysis of recreation demand. Previous studies in the literature employ data on sport fishing trips aggregated over the recreation season.

As previously indicated, the temporal disaggregation was believed to be crucial because fishing opportunities in Alaska change dramatically over the season, as evidenced by salmon runs and the opening and closing of fishing sites for particular species. Moreover, for species that are available throughout the season, such as trout, the quality of fishing at specific sites can vary substantially over the season. By estimating a weekly model of fishing behavior, we were able to capture this variation in fishing conditions and to obtain a more accurate assessment of the impact of variable quality on the behavior of Alaskan anglers.

The conceptual economic decision model underlying angler behavior is exhibited using a weekly time dimension (figure 2). The angler is first assumed to decide whether to go fishing at all during the week (participation) and, if so, to then choose how many times to go sport fishing (intensity of participation) — once, twice, or more than twice. Given that the individual is making a fishing trip, he is assumed to select first a target species (table 1), or no target species, and then a site (table 2) at which to fish for the given target species. (The original list of sites from which the respondents had to choose included 80 fishing areas.)

The set of sites available for species selection varied by species. Not all sites were open for fishing for particular species in every week $t$ of the season. The species choice actually involved two steps. It was assumed that the angler first chose a "macro species" $s$ (i.e., salmon, freshwater, saltwater, or no target species) and then selected a particular subspecies $r$ (e.g., king salmon versus red salmon) prior to choosing a specific site $i$.

Within this structure, the elemental items (the choices at the bottom of the tree) are not fishing in a particular week, or fishing for a particular species (or for no target species) at a particular site that week. The objective, therefore, was to estimate the probability that an Alaska resident angler makes a fishing trip in week $t$ for the subspecies $r$ of macro species $s$ at site $i$. These elemental probabilities can be expressed as the following product of conditional probabilities:

\footnotetext{
${ }^{17}$ Survey cards were sent to 7,500 households, of whom 3,842 responded.

${ }_{18} 1,110$ households responded to this survey.

${ }^{19} 695$ households responded to this survey. In addition, a combined, season-long survey was sent to non-respondents from the August survey; this elicited 593 responses.
} 
Whether to Go Sport Fishing this Week? And, If So, How Many Trips to Take?

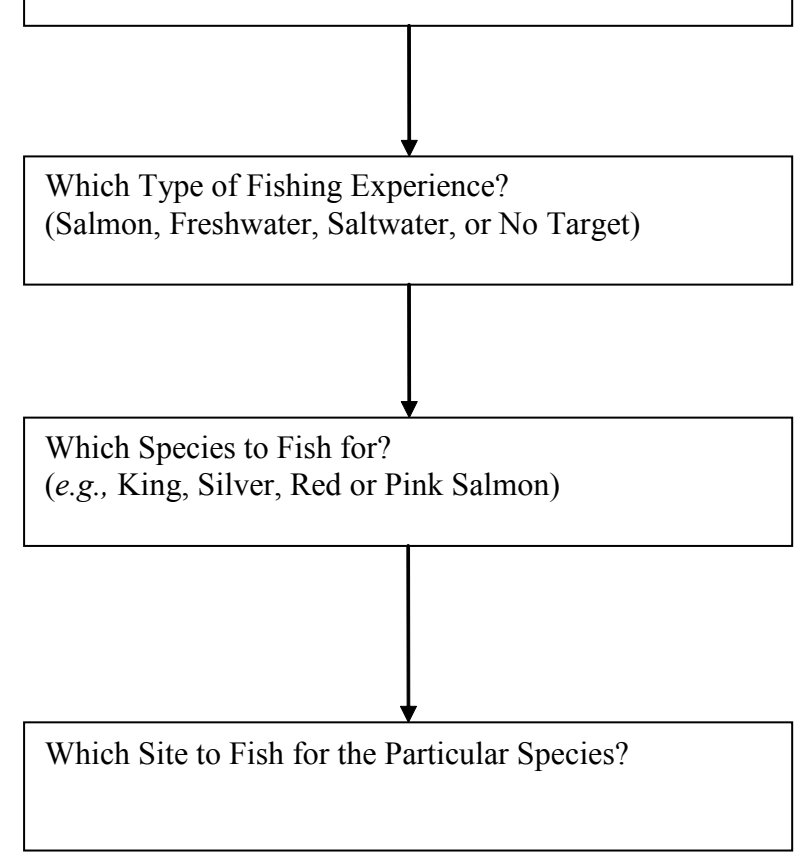

Figure 2. Conceptual Decision Tree for Analyzing Resident Angler Demand for Sport Fishing

Table 1

Species Groups (and Abbreviations) Used for the Analysis of Sport Fishing Demand

\begin{tabular}{ll}
\hline Group & \multicolumn{1}{c}{ Species Group } \\
\hline 1 & King salmon (KS), including small king salmon (KI) \\
2 & Red salmon (RS) \\
3 & Silver salmon (SS) \\
4 & Pink salmon (PS) \\
5 & Rainbow trout (RT) and land-locked salmon (LL) \\
6 & Dolly Varden (DV) and Arctic char (AC) \\
7 & Lake trout (LT) \\
8 & Arctic grayling (GR) \\
9 & Other freshwater species—chum salmon (CS), steelhead trout (SH), cutthroat trout \\
& (CT), brook trout (BT), northern pike (NP), shellfish (SF), whitefish-freshwater \\
10 & Halibut (HA) \\
11 & Razor clams (RC) \\
12 & Other saltwater species—-rockfish/seabass (RF/SB), smelt/hooligan/capelin (SM), \\
& other finfish (OF), whitefish-saltwater (WFS), other shellfish (OS) \\
\hline
\end{tabular}


Table 2

Sport Fishing Sites Used for the Analysis of Resident Angler Sport Fishing Demand

Site

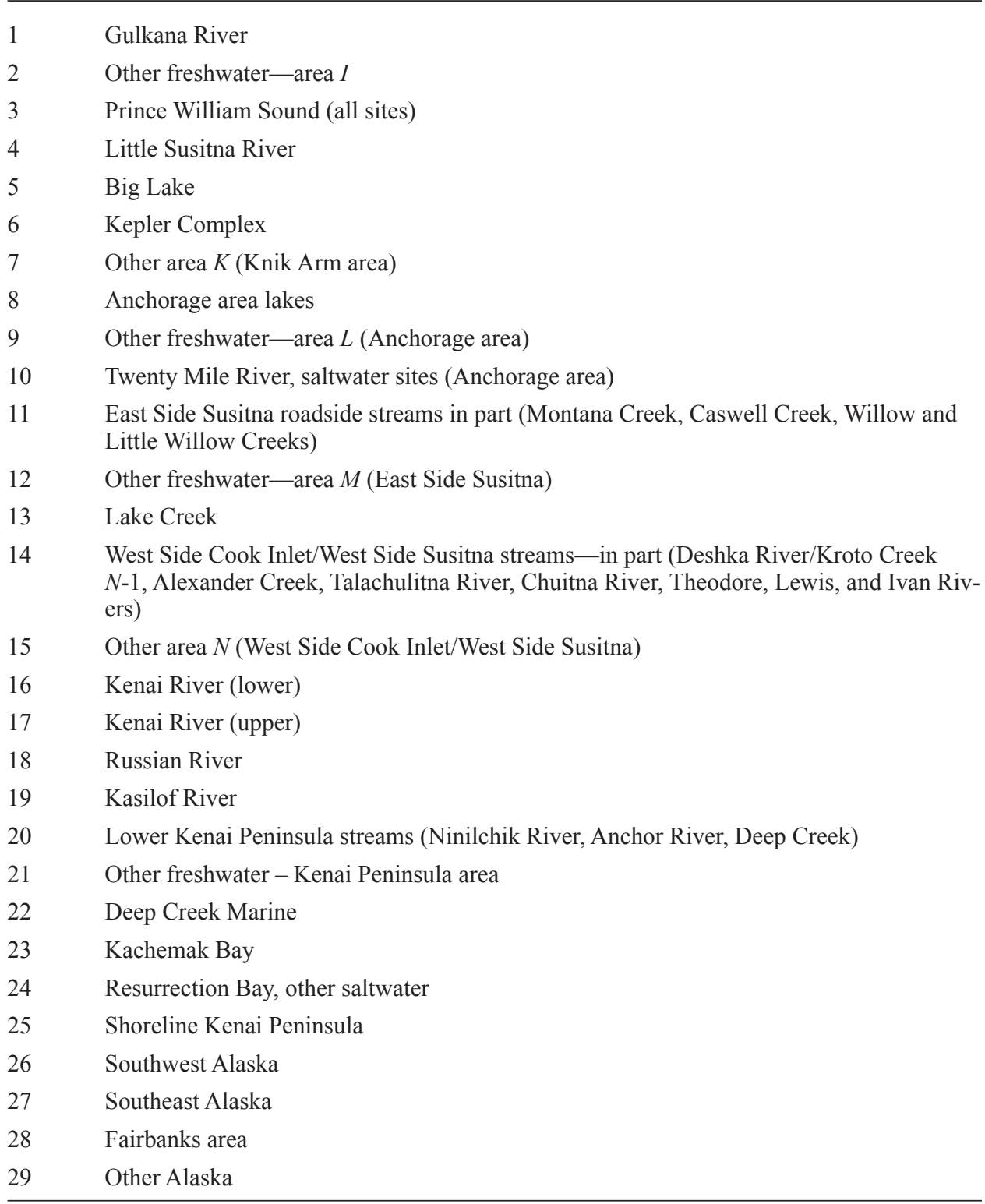

where:

$$
\operatorname{Prob}_{i r s t}=\operatorname{Prob}_{i / r s t} \cdot \operatorname{Prob}_{r / s t} \bullet \operatorname{Prob}_{s / t} \bullet \operatorname{Prob}_{F t} \text {, }
$$

Prob $_{i / r s t}=$ the probability that an Alaskan resident angler selects site $i$ given that he makes a fishing trip for subspecies $r$ of macro species $s$ in week $t$; 
$\operatorname{Prob}_{r / s t}=$ the probability that an Alaskan resident angler selects subspecies $r$ given that he makes a fishing trip for macro species $s$ in week $t$;

$\operatorname{Prob}_{s / t}=$ the probability that an Alaskan resident angler selects macro species $s$ given that he makes a fishing trip in week $t$; and

$\operatorname{Prob}_{F t}=$ the probability that an Alaskan resident angler makes at least one fishing trip during week $t$.

This decomposition is exploited in the estimation of the statistical model. Instead of estimating the elemental probabilities directly, we sequentially estimate each of the conditional probabilities on the right-hand side of equation (1). Thus, we start by estimating the conditional site selection probabilities $\left(\operatorname{Prob}_{i / r s t}\right)$ for each of the 12 distinct fish subspecies plus a "no target" species alternative. Next, we estimate the conditional species selection probabilities $\left(\operatorname{Prob}_{r / s t}, \operatorname{Prob}_{s / t}\right)$. Finally, we estimate the participation and intensity of participation probabilities $\left(\operatorname{Prob}_{N t}, \operatorname{Prob}_{1 t}, \operatorname{Prob}_{2 t}, \operatorname{Prob}_{3 t}\right)$, where:

$\operatorname{Prob}_{N t}=$ the probability that an Alaskan resident angler does not make any fishing trips during week $t$;

$\operatorname{Prob}_{1 t}=$ the probability that an Alaskan resident angler makes one fishing trip during week $t$;

$\operatorname{Prob}_{2 t}=$ the probability that an Alaskan resident angler makes two fishing trips during week $t$;

$\operatorname{Prob}_{3 t}=$ the probability that an Alaskan resident angler makes three or more fishing trips during week $t$.

\section{Angler Site Selection Choice}

The overall decision tree in figure 2 is modeled as a generalized logit model. This structure generates a simple logit model for the site selection probabilities on any trip for the given species in the given week:

$$
\operatorname{Prob}_{i / r s t}=\frac{e^{W_{i r s t}}}{\sum_{i^{\prime}=1}^{N_{r s}} e^{W_{j r s t}}} i=1, \ldots, N_{r s} .
$$

One of these models is used for each subspecies, $r$, of every macro species, $s$. That is, there are 13 such models (including the model for no target species trips). The detailed nature of the model is displayed in figure 3.

The term $W_{\text {irst }}$ in equation (2) represents a linear combination of variables and coefficients and can be thought of as an index of the desirability of fishing at site $i$, given that one is making a trip for subspecies $r$ of macro species $s$ in week $t$. This term is a linear function of the variables described below, multiplied by the estimated coefficients. 


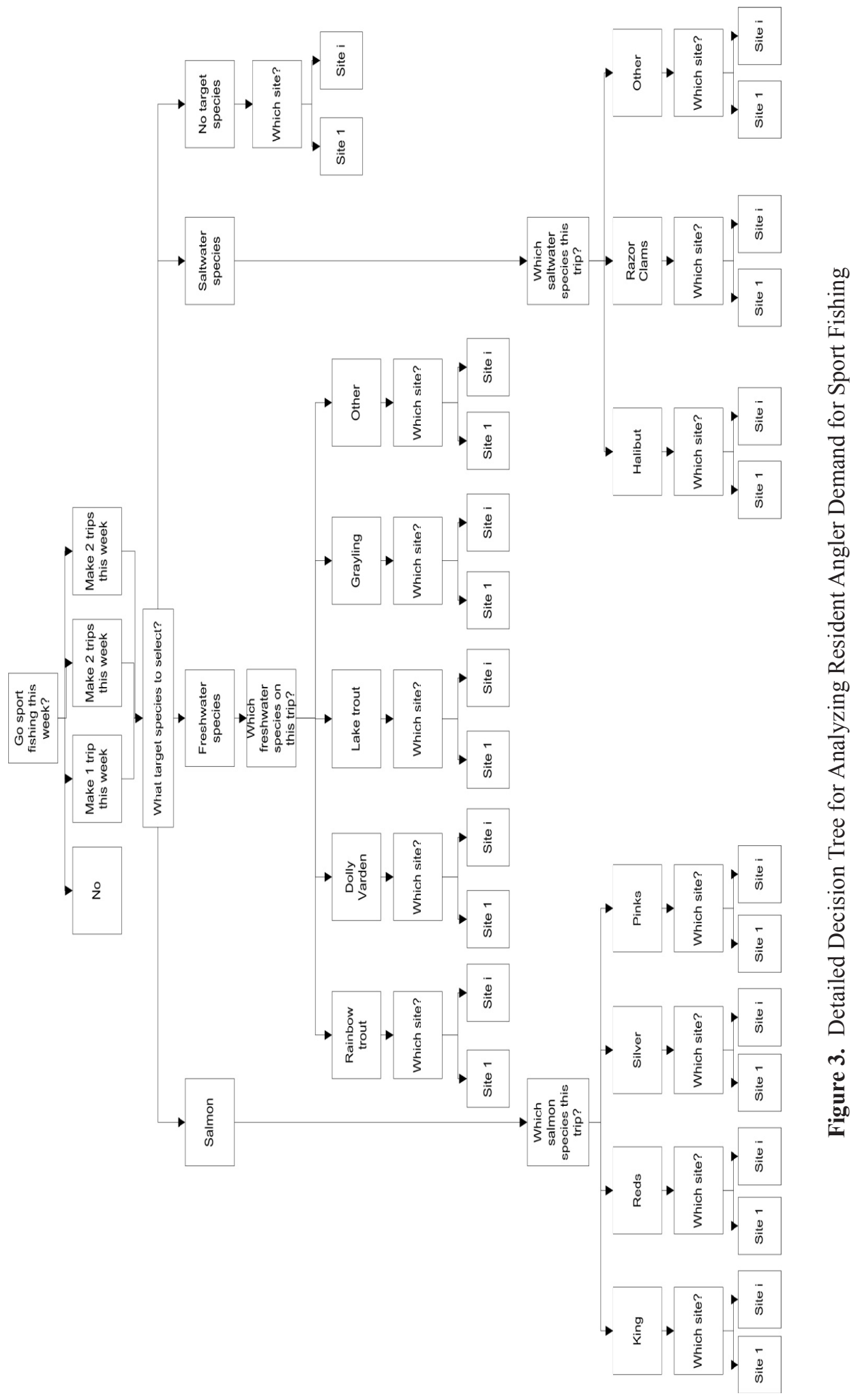


Travel Cost ${ }_{i}$ : Round-trip travel cost from origin zones to site $i$ for road-access sites. This cost was computed as round-trip distance multiplied by the individual respondent's reported motor vehicle cost per mile. For sites 13-15 (Lake Creek, Westside Susitna streams, and others), 26 and 27 (Southwest and Southeast Alaska), and 29 (other Alaska), this cost is computed on the basis of estimated round-trip flying cost from the origin zone to the site. Round-trip train costs were added for trips involving passage between Portage and Whittier. For certain sites and species combinations in which fishing from a boat is common (all sport fishing at Deep Creek Marine, Kachemak Bay, and Resurrection Bay; salmon fishing in Prince William Sound; and sport fishing for halibut and other saltwater species at Prince William Sound, Kenai Peninsula shoreline, and Southwest, Southeast, and other Alaska), a boating cost is added to the round-trip travel cost.

Site Rating : $_{i t}$ A species-specific index of the quality of fishing at site $i$ in week $t$. This index initially ranged from 1 (very poor) to 8 (excellent). The rating then was normalized to account for weekly variation by dividing the weekly rating by the mean rating for the site over the season. The rating for other saltwater species (group 12) was not normalized because a catch variable was not used for this species group.

Fish Rating: $\left(\right.$ Salmon $_{i t}$, Freshwater ${ }_{i}$ Saltwater $_{i}$ ) A general index of the quality of fishing for each macro species at site $i$ (and in week $t$ for salmon) used in the site selection model for trips with no target species. The index rating ranged from 0 (not available) to 4 (excellent).

Developed $_{i}$ : A dummy variable taking the value 1 if site $i$ is developed with boat and tourist facilities; 0 otherwise.

Crowd $_{i t}$ : A measure of crowding conditions at site $i$ in week $t$ as they affect individual respondents. Computed as the product of the individual respondent's crowding tolerance index (positive if the individual likes crowded conditions, negative if he dislikes them), and a measure of crowding conditions at the site that week $(0=$ not crowded, $1=$ somewhat crowded, 2 = very crowded). CROWD is 0 if either the site is not crowded or the individual is indifferent to crowding; it is large and negative if the site is crowded and the individual strongly dislikes crowding; it is large and positive if the site is crowded and the individual prefers crowded sites.

Cabin $_{i}$ : A dummy variable taking the value 1 if the individual respondent owns or has regular access to a private cabin at site $i$; 0 otherwise.

1985 Harv $_{i}$ : This variable measures the total number of species caught (in thousands) at different sites in 1985 .

The particular variables used and the estimated coefficients differ from species to species, and the results are presented in table 3. In the case of king salmon fishing trips, for example:

$$
\begin{gathered}
W_{i r s t}=-0.9468 \cdot \ln \left(\operatorname{TRAVEL~COST}_{i}\right)+0.9589 \cdot \mathrm{SITE} \mathrm{RATING}_{i t} \\
+0.5376 \cdot 1 n\left(1985 \mathrm{HARV}_{i}\right)+2.1272 \cdot \mathrm{CABIN}_{i}+0.1764 \cdot \mathrm{CROWD}_{i t}
\end{gathered}
$$

Thus, a site is more attractive to king salmon anglers if it has good quality fishing that week, the site had a large catch in 1985, the individual owns or has access to a cabin nearby, it is less crowded that week, or it is less expensive for the individual to reach.

The other sets of coefficients in table 3 are used to form the $W_{\text {irst }}$ indices for the other species in the same manner as equation (3). All coefficients have the same signs as in the king salmon site selection model. In addition, DEVELOPED, which is not a variable in 


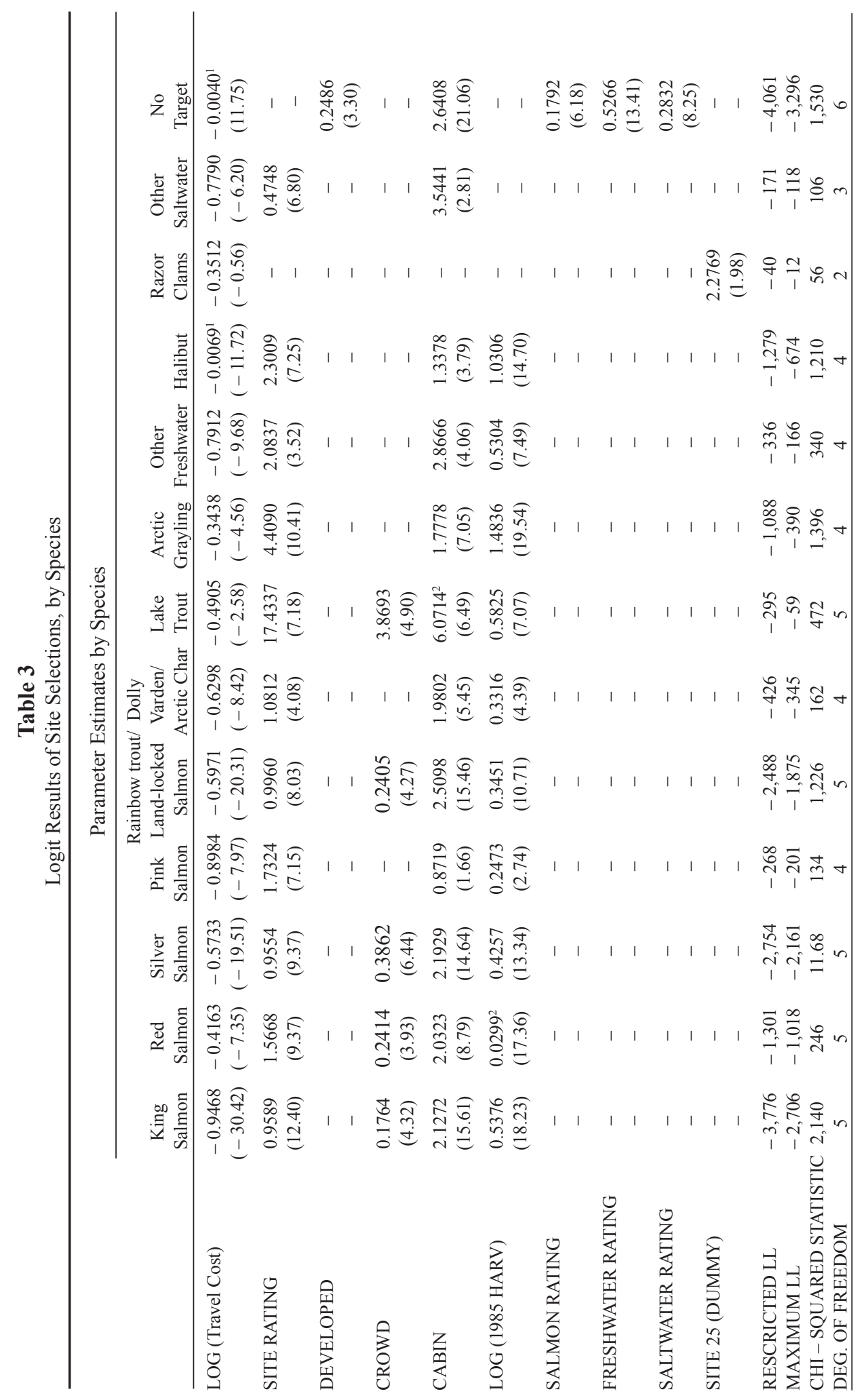


equation (3), has a significant positive coefficient for no target species. In this case, anglers appear to favor developed sites over non-developed sites.

The model for razor clams has a particularly simple structure because there are only two sites, Kenai Peninsula shoreline (site 25) and other West Side Susitna (site 15), in the choice set. In this case:

$$
W_{i r s t}=\begin{aligned}
& 2.2769-0.3512 \ln \left(\operatorname{TRAVELCOST}_{i}\right) \text { for site } 25 \\
& -0.3512 \ln \left(\mathrm{TRAVELCOST}_{i}\right) \text { for site } 15
\end{aligned}
$$

\section{Angler's Species Selection Choice}

Using the generalized logit formulation the subspecies selection probabilities take the form:

$$
\operatorname{Prob}_{r / s t}=\frac{e^{W_{r s t}}}{\sum_{r=1}^{R_{2}} e^{W_{r s t}}} \quad r=1, \ldots, R_{s}
$$

where $W_{r s t} \equiv \alpha_{r}+\delta_{r} I_{r s t}$ and the $\alpha_{r}$ 's and $\delta_{r}$ 's are coefficients to be estimated, while $I_{r s t}$ is a variable known as the "inclusive value." This value is constructed from the coefficients of the site selection model according to the formula:

$$
I_{r s t}=\ln \left(\sum_{i=1}^{N_{r s}} e^{W_{j r s t}}\right) .
$$

Recall that $W_{i r s t}$ is an index of the desirability of site $i$ where one is making a trip for subspecies $r$ of macro species $s$ in week $t$. It follows, therefore, that $I_{r s t}$ is an index of the overall quality of fishing opportunities for subspecies $r$ of macro species $s$ in week $t$, averaged over all the sites at which the species is available in that week. The term $W_{r s t}$ in equation (5) can be interpreted as an index of the desirability of subspecies $r$ in week $t$ relative to the other subspecies within a given macro species, $s$. This index is modeled here as a function of an intercept $\left(\alpha_{r}\right)$ as well as the inclusive value. (Using the inclusive value to link the factors entering a lower level decision - site selection- to the determination of a higher level decision - subspecies selection-is a distinctive feature of the generalized logit model.)

The coefficients $\alpha_{r}$ and $\delta_{r}$ can be interpreted as preference weights. Since the inclusive values vary weekly and capture weekly variations in the quality of fishing conditions for each subspecies, the coefficient $\delta_{r}$ (which should be positive) can be thought of as a weight placed on the effects of fishing for subspecies $r$, which varies over the course of the season. By contrast, the intercept $\alpha_{r}$ captures that part of the individual preference for the subspecies that is not keyed to factors that vary over the season. The logic of the logit model requires that one of the intercepts be normalized to zero and that the others are measured relative to it and thus can be positive or negative. If $\alpha_{r}$ is large in absolute value and $\delta_{r}$ is close to zero, the probability of selecting subspecies $r$ will not be affected much by weekly variations in fishing conditions for the species (although the site selection probabilities may still be sensitive to such variation); an example is halibut within the 
saltwater macro species. Conversely, if $\alpha_{r}$ is close to zero and $\delta_{r}$ is large, the subspecies selection probabilities are highly responsive to weekly fluctuations in conditions.

Maximum likelihood estimates of the coefficients $\left(\alpha_{r}, \delta_{r}\right)$ for each of the subspecies in macro species ( $s=$ salmon, freshwater, and saltwater) are presented in table 4 . All of the coefficients on the inclusive values have the correct sign; all inclusive value coefficients are significant at standard levels, except for the coefficient on halibut, which is marginally significant, and on other saltwater species, which is close to zero. The fact that the inclusive value coefficient is close to zero for other saltwater species probably reflects the consequence of the heterogeneity of the different types of fish included within this category. There is quite a temporal pattern to the inclusive values, particularly king salmon, which is displayed in figure 4.

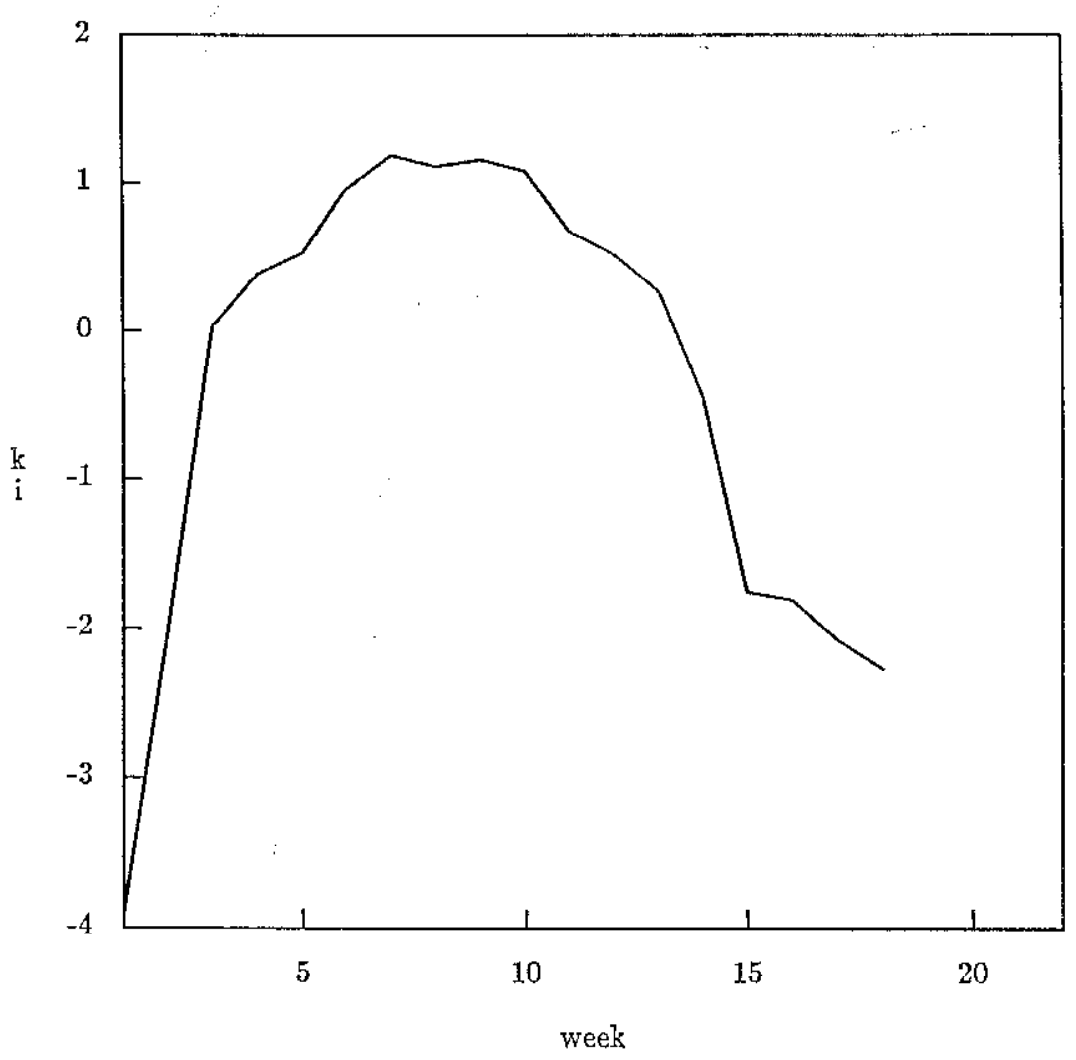

Figure 4. Value of the King Salmon Inclusive Value by Week of Fishing Season 
Table 4

Parameter Estimates for Subspecies Selection Model

\begin{tabular}{|c|c|c|}
\hline \multirow[b]{2}{*}{ Subspecies } & \multicolumn{2}{|c|}{ Parameters } \\
\hline & Constant $\left(\alpha_{r}\right)$ & Inclusive Value $\left(\delta_{r}\right)$ \\
\hline \multicolumn{3}{|l|}{ Salmon Macro Species: } \\
\hline King & $\begin{array}{l}1.2485 \\
(10.70)\end{array}$ & $\begin{array}{l}1.1440 \\
(19.35)\end{array}$ \\
\hline Red & $\begin{array}{l}-3.0194 \\
(-10.03)\end{array}$ & $\begin{array}{l}1.2810 \\
(16.22)\end{array}$ \\
\hline Silver & $\begin{array}{l}-1.3247 \\
(-6.79)\end{array}$ & $\begin{array}{l}1.3597 \\
(20.41)\end{array}$ \\
\hline Pink & $\begin{array}{c}0 \\
\text { (normalized) }\end{array}$ & $\begin{array}{l}0.4493 \\
(7.38)\end{array}$ \\
\hline $\begin{array}{l}\text { Restricted log-likelihood: } \\
\text { Maximized log-likelihood: } \\
\text { Chi-squared statistics: }\end{array}$ & $\begin{array}{l}-3,728 \\
-2,066 \\
1,662\end{array}$ & \\
\hline \multicolumn{3}{|l|}{ Freshwater Macro Species: } \\
\hline Rainbow trout & $\begin{array}{l}-1.0146 \\
(-3.86)\end{array}$ & $\begin{array}{l}1.2261 \\
(13.93)\end{array}$ \\
\hline Dolly Varden & $\begin{array}{l}-2.4593 \\
(-6.46)\end{array}$ & $\begin{array}{l}1.2261 \\
(9.78)\end{array}$ \\
\hline Lake trout & $\begin{array}{l}-2.4267 \\
(-4.63)\end{array}$ & $\begin{array}{l}0.1330 \\
(6.65)\end{array}$ \\
\hline Grayling & $\begin{array}{l}-11.3518 \\
(-13.69)\end{array}$ & $\begin{array}{l}1.2910 \\
(15.76)\end{array}$ \\
\hline Other freshwater & $\begin{array}{c}0 \\
\text { (normalized) }\end{array}$ & $\begin{array}{l}0.5595 \\
(8.29)\end{array}$ \\
\hline $\begin{array}{l}\text { Restricted log-likelihood: } \\
\text { Maximized log-likelihood: } \\
\text { Chi-squared statistic: }\end{array}$ & $\begin{array}{c}-3,045 \\
-2,373 \\
1,344\end{array}$ & \\
\hline \multicolumn{3}{|l|}{ Saltwater Macro Species: } \\
\hline Other saltwater & $\begin{array}{l}1.5753 \\
(2.68)\end{array}$ & $\begin{array}{c}0.0279 \\
(0.18)\end{array}$ \\
\hline Halibut & $\begin{array}{l}1.9708 \\
(1.67)\end{array}$ & $\begin{array}{l}0.2406 \\
(1.38)\end{array}$ \\
\hline Razor clam & $\begin{array}{c}0 \\
\text { (normalized) }\end{array}$ & $\begin{array}{l}0.9755 \\
(2.04)\end{array}$ \\
\hline $\begin{array}{l}\text { Restricted log-likelihood: } \\
\text { Maximized log-likelihood: } \\
\text { Chi-squared statistic: } \\
\text { t-statistics in parentheses. }\end{array}$ & $\begin{array}{c}-907 \\
-498 \\
818\end{array}$ & \\
\hline
\end{tabular}


The four macro species are salmon, freshwater, and saltwater $(s=1,2,3)$ and no target species $(s=4)$. The macro species selection probabilities take the form:

$$
\operatorname{Prob}_{s / t}=\frac{e^{W_{s t}}}{\sum_{s=1}^{4} e^{W_{s t}}} \quad s=1, \ldots, 4
$$

The term $W_{s t}$ is an index of the relative attractiveness of each species (or of not having a target species) to an angler taking a fishing trip in a particular week. As we modeled them, they are functions of the following variables:

D Income: Discretionary income per choice occasion (i.e., trip) in thousands of dollars. For each of seven income groups, annual discretionary income was first computed as a proportion of pretax household income using U.S. Bureau of Labor Statistics information for Alaska. Categories of discretionary income included: food away from home $(50 \%)$, alcoholic beverages, automobile expenses $(50 \%)$, entertainment, reading materials, and cash contributions. Summer discretionary income was computed by multiplying the annual amount by .42 (the percentage of summer weeks). Summer discretionary income was then divided by the number of sport fishing trips (choice occasions) that the individual took over the summer.

Site Focus: A dummy variable taking the value 1 if the individual indicated that the choice of a site was more important to him than the choice of a target species; 0 otherwise.

Boatown: A dummy variable taking the value 1 if the individual owns a boat; 0 otherwise.

Trophy: A dummy variable taking the value 1 if the individual prefers trophy sport fishing; 0 otherwise.

Release: A dummy variable taking the value 1 if the individual prefers catch-and-release sport fishing; 0 otherwise.

$I_{s t}$ : An inclusive value index measuring the overall quality of sport fishing opportunities for macro species, $s$, in week $t$. For $s=1,2,3$, this value is calculated according to the following formula:

$$
I_{s t}=\ln \left(\sum_{r^{\prime}=1}^{R_{s}} e^{W_{r^{\prime} s t}}\right),
$$

while $I_{4 t}$ is given by the right-hand side of equation (6) computed as $s=4$. The general formula for these terms is:

BOATOWN

$W_{s t}=\gamma_{s}+\eta_{s}$ DINCOME $+\beta_{1 S}$ SITE FOCUS $+\beta_{2 s}\{$ TROPHY $\}+\theta_{S} I_{S T},(9)$ 
and $\gamma_{s}, \eta_{s}$, and $\beta_{s}$ are coefficients to be estimated. As with the subspecies model, the coefficient of inclusive value $\left(\theta_{s}\right)$ serves as the weight placed on the aspects of fishing for macro species, $\theta_{s}$, which varies during the course of the season; the term $\left(\gamma_{s}+\eta \mathrm{D}\right.$ IN$\mathrm{COME}+\beta_{1 S}$ SITE FOCUS $+\beta_{2 s}$ BOATOWN/TROPHY/RELEASE) captures that part of the individual's preference for the macro species that is not keyed to factors that vary over the season.

Maximum likelihood estimates of the coefficients $\gamma_{s}, a \eta_{s}, \beta_{1 s}, \beta_{2 s}, \theta_{s}$ for $s=1, \ldots, 4$ are presented in table 5 . One of the intercepts and income coefficients must be normalized to zero, and the others are measured relative to it. In this case, we normalized on no target species, and we took the negative of its price (travel cost) coefficient in table 3 as the marginal utility of income for no target trips. This term then was added to $\eta_{s}(\mathrm{~s}=1,2,3)$ to obtain the estimated marginal utility of income for specific marco species fishing trips. The largest income coefficients in table 5 are for saltwater and salmon, indicating that these species have the highest income elasticities of demand. The income coefficient for freshwater species is negative but not significant, indicating that it has a lower income elasticity than no target species. The SITE FOCUS coefficients indicate that, for freshwater trips, the site is a more important factor than the particular subspecies; the reverse is true for salmon and saltwater trips.

Table 5

Parameters Estimates for Macro Species Selection Model

\begin{tabular}{|c|c|c|c|c|c|c|c|}
\hline \multirow[b]{2}{*}{$\begin{array}{l}\text { Macro } \\
\text { Species }\end{array}$} & \multicolumn{7}{|c|}{ Parameters } \\
\hline & $\begin{array}{c}\text { Intercept } \\
\left(\gamma_{s}\right)\end{array}$ & $\begin{array}{c}\text { DINCOME } \\
\left(\eta_{s}\right)\end{array}$ & $\begin{array}{l}\text { Inclusive } \\
\text { Value } \\
\left(\theta_{s}\right)\end{array}$ & $\begin{array}{l}\text { SITE } \\
\text { FOCUS } \\
\quad\left(\gamma_{1 s}\right)\end{array}$ & $\begin{array}{l}\text { BOATOWN } \\
\left(\beta_{2 s}\right)\end{array}$ & $\begin{array}{c}\text { TROPHY } \\
\left(\beta_{2 s}\right)\end{array}$ & $\begin{array}{c}\text { RELEASE } \\
\left(\beta_{2 s}\right)\end{array}$ \\
\hline Salmon & $\begin{array}{l}0.9556 \\
(4.91)\end{array}$ & $\begin{array}{l}3.8803 \\
(3.97)\end{array}$ & $\begin{array}{l}0.8260 \\
(25.86)\end{array}$ & $\begin{array}{l}-0.3459 \\
(-4.21)\end{array}$ & $\begin{array}{l}- \\
- \\
-\end{array}$ & $\begin{array}{l}0.3765 \\
(5.37)\end{array}$ & $\begin{array}{l}- \\
-\end{array}$ \\
\hline Freshwater & $\begin{array}{l}-0.4568 \\
(-2.13)\end{array}$ & $\begin{array}{c}(-0.4907) \\
(-0.46)\end{array}$ & $\begin{array}{l}0.9728 \\
(18.60)\end{array}$ & $\begin{array}{l}0.1815 \\
(2.18)\end{array}$ & $\begin{array}{l}- \\
-\end{array}$ & $\begin{array}{l}- \\
- \\
-\end{array}$ & $\begin{array}{l}0.6050 \\
(9.82)\end{array}$ \\
\hline Saltwater & $\begin{array}{l}-14.2746 \\
(-13.32)\end{array}$ & $\begin{array}{l}6.9863 \\
(6.34)\end{array}$ & $\begin{array}{l}4.2851 \\
(14.78)\end{array}$ & $\begin{array}{l}-0.3861 \\
(-3.49)\end{array}$ & $\begin{array}{l}0.4563 \\
(5.94)\end{array}$ & $\begin{array}{l}- \\
-\end{array}$ & $\begin{array}{l}- \\
-\end{array}$ \\
\hline No target & $\begin{array}{c}0 \\
\text { (normalized) }\end{array}$ & $\begin{array}{c}0 \\
\text { (normalized) }\end{array}$ & $\begin{array}{l}0.8583 \\
(12.82)\end{array}$ & $\begin{array}{c}0 \\
\text { (normalized) }\end{array}$ & $\begin{array}{l}- \\
-\end{array}$ & - & $\begin{array}{l}- \\
-\end{array}$ \\
\hline
\end{tabular}

Restricted log-likelihood: $-9,448$

Maximized log-likelihood: $-8,007$

Chi-squared statistic: $\quad 2,882$

$t$-statistics in parentheses.

\section{Angler's Fishing Participation and Intensity Choice}

As depicted at the top of the decision tree in figure 1, the angler decides whether to go fishing during week $t$ and, if so, how many trips to make-one, two, or more than two. The formulas for the fishing participation probabilities are: 


$$
\operatorname{Prob}_{i t}=\frac{e^{W_{i t}}}{e^{W_{N t}}+e^{W_{1 t}}+e^{W_{2 t}}+e^{W_{3 t}}} \quad i=1,2,3
$$

which is the probability that the angler makes one $(i=1)$, two $(i=2)$, or more than two $(i$ $=3$ ) fishing trips during the week, and

$$
\operatorname{Prob}_{N t}=\frac{e^{W_{N t}}}{e^{W_{N t}}+e^{W_{1 t}}+e^{W_{2 t}}+e^{W_{3 t}}}
$$

is the probability that he does not make any fishing trips during that week. The mean number of trips taken by those with more than two trips was 3.63; the majority (63\%) of cases with more than two trips during a week involved three trips. The expected number of trips by an angler during week $t\left(X_{t}\right)$ can be estimated as: $X_{t}=\operatorname{Prob}_{1 t}+2 \cdot \operatorname{Prob}_{2 t}+3.63$ - Prob $_{3 t}$.

The terms $\mathrm{W}_{N t}$ and $\mathrm{W}_{T}, T=1,2,3$ in equations (10) and (11) are indices of the relative attractiveness to an angler of not taking a fishing trip in week $t$, or of taking one, two, or more than two trips.

The logic of the generalized logit model is that these terms are functions of the inclusive value computed from the macro species selection model. The terms $W_{N t}$ and $W_{T t}$,

$$
I_{F t}=\ln \left(\sum_{s^{\prime}=1}^{4} e^{W_{s t}}\right)
$$

which measure the overall quality of sport fishing in Alaska in week $t$, as weighted by individual angler preferences and other variables. The other variables used in the analysis are:

JUL4HOL $_{t}$ : A dummy variable which takes the value 1 if the week contains the July 4 holiday; 0 otherwise.

LOTEMP $_{t}$ : A dummy variable which takes the value 1 when the weekly low temperature in Anchorage is below $40^{\circ} \mathrm{F} ; 0$ otherwise.

LEISURE: An index of the amount of leisure time available to the individual angler, based on a factor analysis of the response to question 5 in section 1 of QI and the combination questionnaire.

OWN: A dummy variable which takes the value 1 if the individual owns a cabin, boat, or $\mathrm{RV} ; 0$ otherwise.

SKILL: An index of the individual's experience in sport fishing, based on the response to question 7 in Section I of QI and the combination questionnaire. This index ranges from 1 (novice) to 4 (expert angler).

AVLONG: The average length in days of all fishing trips taken by the individual in Alaska over the 1986 summer season. 
The term $W_{s t}$, the angler's "baseline" utility associated with not fishing, is normalized to zero:

$$
W_{N t}=0 \text {. }
$$

The other $W_{s t}$ terms are expressed as functions of an intercept and the explanatory variables listed above:

$$
\begin{aligned}
W_{T t}= & B_{T 0}+B_{T 1} \bullet \mathrm{LEISURE}+B_{T 2} \bullet \mathrm{OWN}+B_{T 3} \bullet \mathrm{SKILL} \\
& \left.+B_{T 4} \bullet \mathrm{AVLONG}+B_{T 5} \bullet \mathrm{JUL} 4 \mathrm{HOL}+B_{T 6} \bullet \mathrm{LOTEMP}+B_{T 7} \bullet I_{f t}(13)\right) \\
= & W_{t}+B_{T 7} I_{F T} .
\end{aligned}
$$

These functions, estimated by maximum likelihood, are presented in table 6 . The constant terms are negative (i.e., less than $W_{N}$ ), but when the other terms in the formula are evaluated, the $W_{i t}$ 's may be positive.

The coefficients in table 6 are almost all significant and correspond well to expectations. Anglers who make longer trips also take fewer trips and are less likely to make multiple trips in a week. (The coefficients of AVLONG are negative and become uniformly more negative when moving from $W_{1 t}$ to $W_{3 t}$.) The people with the most leisure time in our sample tend to be retired. When compared to the average angler, they are less likely to take one trip but more likely to take two or more trips. Anglers who own a boat, cabin, or RV, or who are more skilled, are more likely to go fishing; they are also likely to take more trips. During the week of the July 4 holiday, all anglers are more likely to take a fishing trip, but the holiday has no impact on whether they take more than one trip. The quality of fishing opportunities each week, as measured by the inclusive value of $I_{F t}$, has significant positive impacts on the likelihood of taking a fishing trip that week and on the number of trips. There is also an interesting time dimension to these impacts. The estimated model allows for separate coefficients on $I_{F t}$ for the early season (the first 13 weeks, through July 31) and the later season. The impact of good fishing quality on fishing trips is significantly greater in the early season than the later part of the season. Figure 5 displays the actual and predicted pattern of recreation over the fishing season.

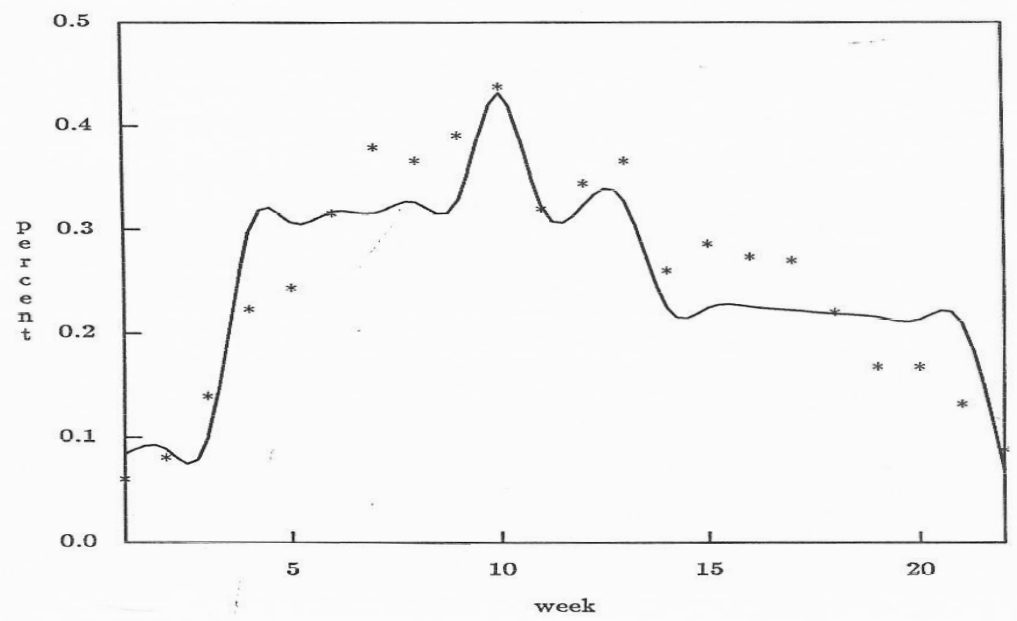

Figure 5. Actual and Predicted Percent of Fishing Households Taking One or More Fishing Trips by Week of the Season 


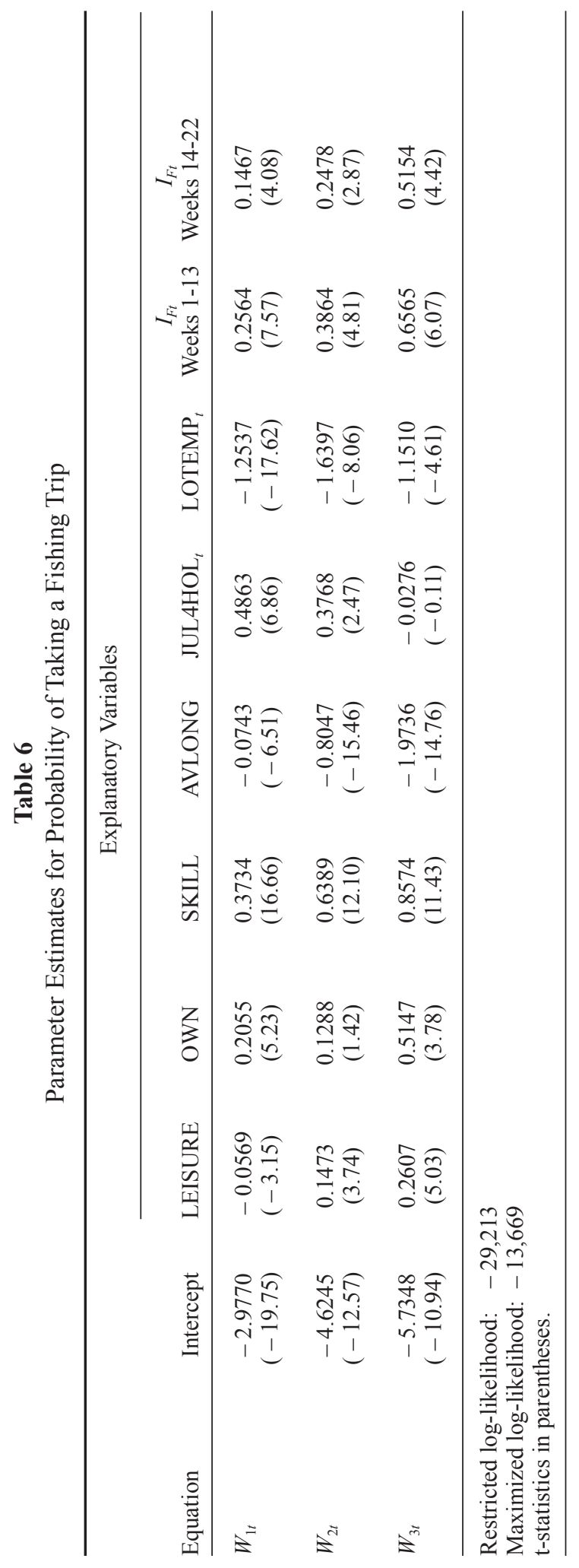




\section{Residents' Decision on Sport Fishing Participation}

In addition to analyzing angling behavior as depicted in figure 1, we also evaluated the decision of Alaska residents regarding any participation in sport fishing. This decision was analyzed using the logit model of the following form:

$$
\text { Probability of angler household }=\frac{1}{1+e^{-W}},
$$

where the term $W$ represents a linear combination of variables and coefficients, and a higher value of $W$ raises the probability of a sport fishing household.

From the initial survey, we had data on both fishing and non-fishing households. The explanatory variables available from the survey included:

HSNUM: The number of persons in the household.

FPREV: A dummy variable taking the value 1 if any members of the household had fished during 1983-1985; 0 otherwise.

YRALASKA: The number of years that household members had lived in Alaska (with 0.5 the minimum value).

FAIRBANKS: A dummy variable taking the value 1 for Fairbanks area households; 0 otherwise.

A maximum likelihood procedure was used to estimate the $W$ term and resulted in the following equation:

$$
\begin{aligned}
& W=-0.743+0.672 \cdot \ln (\mathrm{HSNUM})+3.037 \cdot \mathrm{FPREV}-0.266 \bullet 1 n(\text { YRALASKA })-0.238 \cdot \text { FAIRBANKS } \\
& \text { (5.11) (7.64) (29.66) (5.83) (2.07), }
\end{aligned}
$$

where the $t$-statistics are in parentheses, the restricted log-likelihood is $-5,326$, and the maximized log-likelihood is $-2,901$. Thus, members of large households and household members who had previously sport fished in Alaska were more likely to fish in Alaska in 1986. Newer Alaska residents were somewhat more likely to go fishing than longerestablished residents, although the effect is reduced as the length of residence increases. Finally, residents of Fairbanks are slightly less likely to go fishing than other persons in our sample, primarily Anchorage residents.

\section{Application of the Modeling System}

The estimated model can be used to derive estimates of net willingness to pay of anglers for different fishing opportunities and to analyze the effects on demand from changing fishing quality parameters. Results from both applications are reported.

\section{Estimates of Net Willingness to Pay}

Hanemann (1985) shows how estimates of net willingness to pay (the dollar amount over and above actual expenditures) for sport fishing opportunities can be derived from fitted logit models. For this study, a considerably more complex model—a four-level nested 
generalized logit model — was developed, but a similar methodology applies. The specific formulas, however, become extremely complex and, in some cases, require numerical integrations that were beyond the time and resources available for the study. As a result, less complex approximations were employed.

The basic concept in valuing a particular type of sport fishing-for example, sport fishing for king salmon on the Kenai River-is that every time an individual goes on a fishing trip, he benefits from the existence of that particular fishing opportunity. The generalized logit model derives from a random utility maximization model in which individual choices can be described only in probabilistic terms. Consequently, regardless of whether an individual actually chooses the specific fishing alternative on a particular fishing trip, there is some probability that he might select it and, therefore, he derives some benefit from its existence when making his fishing choice.

A direct link exists between the probability of selecting a site and its benefits. It can be shown that the higher the probability of selecting an alternative, the greater the benefit from its existence. The benefit is measured in terms of the maximum amount of money the individual would be willing to pay to ensure that the alternative is available whenever he makes a fishing choice. We, therefore, obtain an estimate of benefit per choice occasion (i.e., per fishing trip to any site, not just per trip to the particular site of interest). Because our model is estimated on a weekly basis, the benefit to a resident angler is the benefit per choice occasion during that week, multiplied by the predicted number of trips (choice occasions) that week. The total benefit for the entire summer recreation season is the sum of the weekly benefits over the season. These values are reported in table 7.

\section{Table 7}

WTP Estimates for Summer Sport Fishing Opportunities

\begin{tabular}{|c|c|c|}
\hline Site/Species & $\begin{array}{c}\text { Average Net Per } \\
\text { Choice Occasion }(\$)\end{array}$ & $\begin{array}{c}\text { Average Net } \\
\text { WTP (\$) }\end{array}$ \\
\hline Gulkana River-all species & 2.58 & $1,834,000$ \\
\hline Gulkana River_grayling & 0.49 & 346,000 \\
\hline Little Susitna River-king salmon & 1.86 & $1,323,000$ \\
\hline Little Susitna River-silver salmon & 0.82 & 583,000 \\
\hline Big Lake_rainbow trout & 1.61 & $1,141,000$ \\
\hline Anchorage area lakes - rainbow trout, land-locked salmon & 3.00 & $2,127,000$ \\
\hline East Susitna roadside streams-king salmon & 0.81 & 576,000 \\
\hline East Susitna roadside streams - silver salmon & 1.02 & 726,000 \\
\hline Lake Creek-all species & 1.20 & 852,000 \\
\hline West Susitna streams - king salmon & 1.66 & $1,180,000$ \\
\hline West Susitna streams-silver salmon & 0.65 & 485,000 \\
\hline Kenai River_all species & 21.47 & $15,241,000$ \\
\hline Kenai River-king salmon (early run) & 5.69 & $4,038,000$ \\
\hline Kenai River-king salmon (late run) & 3.49 & $2,477,000$ \\
\hline Kenai River-silver salmon (early run) & 3.58 & $2,541,000$ \\
\hline Kenai River-silver salmon (late run) & 2.32 & $1,645,000$ \\
\hline Kenai River-red salmon & 2.41 & $1,711,000$ \\
\hline Kenai River-rainbow trout & 0.97 & 688,000 \\
\hline Russian River-red salmon (early run) & 3.00 & $2,130,000$ \\
\hline Russian River-red salmon (late run) & 0.30 & 211,000 \\
\hline Lower Kenai streams -all species & 2.77 & $1,970,000$ \\
\hline Lower Kenai streams - king salmon & 0.71 & 503,000 \\
\hline Deep Creek Marine_-halibut & 3.32 & $2,357,000$ \\
\hline Deep Creek Marine - king salmon & 1.76 & $1,253,000$ \\
\hline Kackemak Bay-halibut & 7.56 & $5,364,000$ \\
\hline Resurrection Bay-silver salmon & 1.27 & 902,000 \\
\hline
\end{tabular}

Note: Derived by dividing the aggregate new WTP estimates by 709,951 total choice occasions over the season. 


\section{Effect on Demand from Site Closure}

The demand modeling system also was used to analyze the impacts of closing the Kenai River to sport fishing for king salmon during the last week of July (week 13). The Kenai River is generally recognized as the most important king salmon fishery in Southcentral Alaska, and historically the last week in July is the final week in which fishing for earlyrun king salmon occurs in the river.

Potential impacts of closing the fishery during that week include: $i$ ) a change in total sport fishing activity (number of trips) and the reallocation of trips among alternative species and sites; ii) a loss in consumer's surplus (net willingness to pay); and iii) a change in spending on sport fishing. The focus here is on the first impact.

The elimination of a site such as the Kenai River from the choice set for king salmon fishing affects all the probabilities in the model. That is, it affects Prob $_{i r s t}$, for all $i, r, s, t$, and it affects $\operatorname{Prob}_{1 t}, \operatorname{Prob}_{2 t}, \operatorname{Prob}_{3 t}$, and Prob ${ }_{N t}$. For king salmon fishing, it increases the conditional probability (Probi $\mid r, s, t$ ) of visiting all other king salmon sites. However, it also reduces the inclusive value $\left(I_{r, s, t}\right)$ associated with king salmon fishing, which, in turn, has two effects. One effect is to reduce the overall attractiveness of sport fishing during that week, and hence, the total number of fishing trips. The other effect is to reallocate the reduced number of trips to other subspecies of salmon and other macro species of fish.

The impact on the allocation of king salmon fishing trips among other sites is shown in table 8. The first column gives the site selection probabilities for king salmon trips in week 13 under baseline condition (i.e., with the Kenai River open), evaluated for an individual with the average characteristics in the sample. The second column gives the new site selection probabilities after the two Kenai River sites have been eliminated from the choice set for king salmon fishing.

Next, we consider the impact on the choice of subspecies for those who still engage

Table 8

Probability of Taking a King Salmon Trip

During Week 13 to Different Sites when King

Salmon is the Target Species

\begin{tabular}{lcc}
\hline Site & $\begin{array}{c}\text { Probability of } \\
\text { Taking a Trip to Site } \\
\text { with Kenai River } \\
\text { Kings Available }\end{array}$ & $\begin{array}{c}\text { Probability of } \\
\text { Taking a Trip to Site } \\
\text { without Kenai River } \\
\text { Kings Available }\end{array}$ \\
\hline 1 & .0118 & .0351 \\
2 & .0170 & .0455 \\
3 & .0039 & .0097 \\
16 & .4565 & - \\
17 & .2037 & - \\
19 & .1106 & .4492 \\
22 & .0450 & .0285 \\
23 & .0090 & .0566 \\
24 & .0195 & .0278 \\
25 & .0091 & .0249 \\
26 & .0084 & .0366 \\
27 & .0133 & .1231 \\
28 & .0747 & .0292 \\
29 & .0176 & \\
\hline
\end{tabular}


in salmon fishing that week. The elimination of the Kenai River sites lowers the inclusive value associated with king salmon fishing in week 13 from 0.36186 to -0.50567 . Using equation (5), this lower value reduces the probability of selecting king salmon and raises the probability of choosing other subspecies of salmon, given that the individual takes a salmon fishing trip. These changes are exhibited in the first four rows of table 9.

The elimination of king salmon fishing at the Kenai River lowers the overall attractiveness of salmon fishing relative to the other macro species. The inclusive value for the salmon macro species in week 13 falls from 3.0754 to 2.9091 . The consequent reduction in the probability of selecting salmon and the increase in the probability of selecting other target species (or no target) for an angler making a trip in that week are shown in the middle four rows of table 9 .

Finally, the elimination of king salmon fishing at the Kenai River also lowers the overall attractiveness of any fishing in Alaska in week 13. The total inclusive value associated with fishing in that week, $I_{F 13}$, falls from 4.2451 to 4.174 . The impact on the probability of taking one or more fishing trips during week 13, obtained using the formula in equation 12 , is approximately a $1.5 \%$ reduction. Thus, given our baseline estimate of 46,398 fishing trips in week 13, there would be a loss of about 696 fishing trips in total.

The predicted allocation of the remaining trips is based on the probabilities in the last column of table 9. The total number of salmon trips is predicted to fall from 24,818 (= $0.5349 \times 46,398)$ to $22,878(=0.5006 \times 45,702)$, while the total number of king salmon trips falls from $6,041(=0.2434 \times 24,818)$ to $2,438(=0.1066 \times 22,878)$.

As previously indicated, the closure of the Kenai River to king salmon sport fishing also influences angler spending and consumer surplus. Based on the predicted reduction of 696 trips and the reallocation of 45,702 trips to other sport fishing activities, spending by resident anglers associated with sport fishing in Southcentral Alaska would be reduced by $\$ 100,700$. This reduction does not, however, reflect possible increases in angler spending in subsequent weeks due to increased sport fishing activity. The loss in consumer surplus from eliminating king salmon fishing trips on the Kenai River during at week is $\$ 482,000$.

Table 9

Choice Probabilities for Salmon Species, Type of Fishing, and Number of Fishing Trips with and without Kenai River King Salmon Available

\begin{tabular}{lcc} 
& \multicolumn{2}{c}{ Choice Type } \\
\cline { 2 - 3 } & $\begin{array}{c}\text { Probability } \\
\text { with Kenai River } \\
\text { Kings Available }\end{array}$ & $\begin{array}{c}\text { Probability } \\
\text { without Kenai River } \\
\text { Kings Available }\end{array}$ \\
\hline Salmon Species: & & \\
King & .2434 & .1066 \\
Red & .3397 & .4011 \\
Silver & .3277 & .3861 \\
Pink & .0892 & .1054 \\
Types of Fishing: & & \\
Saltwater & .1042 & .1119 \\
Salmon & .5349 & .5006 \\
Freshwater & .2278 & .1446 \\
No target & .1332 & .7123 \\
Number of Fishing Trips: & & .2581 \\
0 & .7083 & .0263 \\
1 & .2614 & .0033 \\
2 & .0269 & \\
3 or more & .0034 & \\
\end{tabular}




\section{Conclusion}

Analysis of the demand for sport fishing in Alaska indicates that site quality is an important determinant of angler behavior. Several measures of site quality were tested and found to be significant in the analysis. A cardinal measure of the quality of sport fishing for a particular species at alternative sites during a specific week proved to be a significant predictor of site choice. Other site quality variables important to site selection included the degree of crowding (in relation to an angler's tolerance to crowding) and the previous year's harvest. The availability of developed facilities such as lodges, boating facilities, and campgrounds was found to be significant only for anglers who did not have a target species.

The discrete choice approach employed proved effective in modeling the structure of angler decisions. This approach worked well within the weekly time dimension because most angler choices (whether to participate, what species to fish for, and what site) could be analyzed as a yes or no decision. The weekly time resolution also enabled us to develop an important link between the quality of sport fishing opportunities and the allocation of fishing activities. This link is especially important in Southcentral Alaska where fishing quality is highly variable as sites open and close and the availability of species at many sites changes frequently.

The richness in detail provided by a temporal demand model, such as the one described in this article, is very useful for fishing management purposes. Important economic effects, such as changes in consumer surplus or angler spending from changes in resource condition (e.g., emergency site closures or fishery stocks), can be evaluated with application of the model. Significant computational time was required, however, to estimate this model because of the interactions between the vast number of site and species combinations, the four levels (or nests) of analysis, and the weekly temporal restoration.

\section{References}

Berry, S.T. 1994. Estimating Discrete Choice Models of Product Differentiation. Rand Journal of Economics 25:242-62.

Binkley, C.S., and W.M. Hanemann. 1978. The Recreation Benefits of Water Quality Improvement: Analysis of Day Trips in an Urban Setting. Report No. EPA-600/5-78010. Washington, DC: U.S. Environmental Protection Agency.

Bockstael, N.E., W.M. Hanemann, and C.L. Kling. 1986. Estimating the Value of Water Quality Improvements in a Recreational Demand Framework. Water Resources Research 23:951-60.

Bockstael, N.E., W.M. Hanemann, and I. Strand. 1986. Measuring the Benefits of Water Quality Improvements Using Recreation Demand Models. Washington, DC: U.S. Environmental Protection Agency.

Bockstael, N.E., I.E. Strand, and W.M. Hanemann. 1987. Time and the Recreational Demand Model. American Journal of Agricultural Economics 69:293-302.

Brown, G.M., and R. Mendelsohn. 1984. The Hedonic Travel Cost Method. Review of Economics and Statistics 66:427-33.

Burt, O.R., and D. Brewer. 1971. Estimation of Net Social Benefits from Outdoor Recreation. Econometrica 39:813-27.

Cardell, S. 1997. Variance Component Structures for Extreme Value and Logistic Distributions with Models of Heterogeneity. Econometric Theory 13:185-213.

Carson, R.T., W.M. Hanemann, and D. Steinberg. 1990. A Discrete Choice Contingent Valuation Estimate of the Value of Kenai King Salmon. Journal of Behavioral Economics 19:53-68. 
Carson, R.T., R.C. Mitchell, W.M. Hanemann, R.J. Kopp, S. Presser, and P.A. Ruud. 1992. A Contingent Valuation Study of Lost Passive Use Values Resulting from the Exxon Valdez Oil Spill. A Report to the Attorney General of the State of Alaska. November 10 .

Clawson, M., and J.K. Knetsch. 1966. Economics of Outdoor Recreation. Baltimore, MD: Johns Hopkins University Press.

Dwyer, J.F., J.R. Kelly, and M.D. Bowes. 1977. Improved Procedures for Valuation of the Contribution of Recreation to National Economic Development. Water Resources Center Report 128, Urbana, IL: University of Illinois.

Freeman, A.M. 1995. The Benefits of Water Quality for Marine Recreation: A Review of the Empirical Evidence. Marine Resource Economics 10:385-406.

Grogger, J.T., and R.T. Carson. 1991. Models for Truncated Counts. Journal of Applied Econometrics 6:225-38.

Gum, R.L., and W.E. Martin. 1975. Problems and Solutions in Estimating the Demand for and Value of Outdoor Recreation. American Journal of Agricultural Economics 57:558-66.

Hagerty, D., and K. Moeltner. 2005. Specification of Driving Costs in Models of Recreation Demand. Land Economics 81:127-43.

Hanemann, W.M. 1978. A Methodological and Empirical Study of the Recreation Benefits from Water Quality Improvement. Ph.D. Dissertation, Harvard University, Cambridge, MA.

. 1984a. Discrete/Continuous Models of Consumer Demand. Econometrica 52:54161.

1984b. Welfare Evaluation in Contingent Valuation Experiments with Discrete Responses. American Journal of Agricultural Economics 66:332-41.

. 1985. Applied Welfare Analysis with Discrete Choice Models. Working Paper, University of California, Berkeley, Department of Agricultural and Resource Economics.

Jones \& Stokes. 1987. Southcentral Alaska Area Sport Fishing Economic Study. Final Report to the Alaska Department of Fish and Game. Sacramento, CA: Jones \& Stokes Associates.

Jones \& Stokes Associates. 1991. Southeast Alaska Sport Fishing Economic Study. Final Research Report. Sacramento, CA: Jones \& Stokes Associates.

Kaoru, Y., V.K. Smith, and J.L. Liu. 1995. Using Random Utility Models to Estimate the Value of Estuarine Resources. American Journal of Agricultural Economics 77:141-51.

Mendelsohn, R.O. 1985. Modeling the Demand for Recreation. Paper presented at Association of Environmental and Resource Economists' Workshop on Recreation Demand Modeling, Boulder, CO.

Morey, E.R. 1981. The Demand for Site-Specific Recreational Activities: A Characteristics Approach. Journal of Environmental Economics and Management 8:245-71.

Morey, E.R., W.D. Shaw, and R.D. Rowe. 1991. A Discrete Choice Model of Recreational Participation, Site Choice and Activity Valuation when Complete Trips are not Available. Journal of Environmental Economics and Management 20:181-201.

Provencher, B., and R.C. Bishop. 1997. An Estimable Dynamic Model of Recreational Behavior with an Application to Great Lakes Angling. Journal of Environmental Economics and Management 33:107-27.

Rowe, R.D., E.R. Morey, A.D. Ross, and W.D. Shaw. 1985. Valuing Marine Recreational Fishing on the Pacific Coast. Report prepared for the National Marine Fisheries Service, National Oceanic and Atmospheric Administration.

Smith, V.K., and Y. Kaoru. 1987. The Hedonic Travel Cost Model: A View from the Trenches. Land Economics 63:179-92.

Smith, V.K., and R.J. Kopp. 1980. Spatial Limits of the Travel Cost Recreational Demand Model. Land Economics 56:64-72. 
Train, K.E. 1998. Recreational Demand Models with Taste Differences over People. Land Economics 74:230-39.

Vaughan, W.J., and C.S. Russell (with C. Paulsen and R. Carson). 1982a. Fresh Water Recreational Fishing: The National Benefits of Water Pollution Control. Washington, DC: Resources for the Future.

1982b. Valuing a Fishing Day: An Application of a Systematic Varying Parameters Model. Land Economics 58: 450-63.

Wegge, T.C., W.M. Hanemann, and I.E. Strand. 1986. An Economic Assessment of Marine Recreational Fishing in Southern California. Report to the National Marine Fisheries Service. Sacramento, CA: Jones \& Stokes Associates, Inc. 
